\title{
A Romanian Consul at the Margins of the Russian Empire: Gheorghe Forescu in Ismail (December 1916 - March 1918) ${ }^{1}$
}

\section{Adrian-Bogdan CEOBANU}

\begin{abstract}
The echoes of the events from the spring of 1917 were also felt in Bessarabia, a province annexed by Russia in 1812 . Their evolution can be analyzed from multiple points of view, including from the perspective of an official representative of the Romanian state. On the basis of the reports sent by the Romanian consul in Ismail, I examine the political, social and military situation from Southern Bessarabia during a period with profound implications for the Russian Empire, in general, and this province, in particular. Gheorghe Forescu was appointed to Ismail, first as a temporary substitute, in November 1916, and then as consul, one month later. He remained in southern Bessarabia until March 1918, when the consular post was abolished as a result of the Union of Bessarabia with Romania. More often than not, Forescu had to confront and overcome certain difficult moments, having to take rapid and tough decisions. Most significantly, he formulated policy initiatives that were generally taken into account by the Romanian decision-makers. He held a position which could initially seem not very demanding and rather ordinary, but which proved to be a crucial point of observation in the context of the accelerating pace of events within the Russian Empire more generally and in Bessarabia, in particular.
\end{abstract}

Keywords: Bessarabia, Ismail, consul, Russian Empire

The revolution of February 1917, and implicitly the abdication of Emperor Nicholas II, led to the emergence of a new political and social state of affairs across the entire territory of the Russian Empire, including on its periphery. The echoes of the events from the spring of 1917 were also felt in Bessarabia, a province annexed by Russia in 1812. Their evolution can be analyzed from multiple points of view, including from the perspective of an official representative of the Romanian state. As such, on the basis of the reports sent by the Romanian consul in Ismail, I will examine the political, social and military situation from Southern Bessarabia during a period with profound implications for the Russian Empire, in general, and this province, in particular.

\footnotetext{
1 This work was supported by a grant of the Romanian Ministry of Research and Innovation, CNCS - UEFISCDI, project number PN-III-P1-1.1-TE-2016-1477, within PNCDI III.
} 


\section{The Romanian Consular Network \\ in the Russian Empire. General Considerations}

On the eve of the outbreak of World War I, the Romanian consular network was complex, including extra-European representation. Nonetheless, it had developed slowly after 1878 . According to the laws for the organization of the Ministry of Foreign Affairs, which witnessed numerous changes in the period between the Congress of Berlin and the Great War, the Romanian consulates were of two categories: career consulates, headed by Romanian citizens, and honorary consulates, led by foreigners. Their purpose was well defined: to bolster the interests of the Romanian nationals on the territory of foreign states, and to preserve the Romanian national identity (culture, language, schools); to these, a series of economic, legal and notarial functions were added ${ }^{2}$. For example, in 1911, the Romanian state had consulates of the first category opened in Austria-Hungary, Bulgaria, Russia, the Ottoman Empire, with the proviso that in the latter state there were several consular offices (Constantinople, Ioannina, Bitolia, and Salonica); this was a normal policy, supported by the decision-makers in Bucharest from the end of the $19^{\text {th }}$ century. In the Russian Empire, there functioned the general consulate in Odessa, the consulate in Ismail, and the honorary consulates in Helsingfors, Moscow, Sankt-Petersburg, Rostov on the Don, and Warsaw ${ }^{3}$. The latter ones were opened in the decades before and after the turn of the $20^{\text {th }}$ century, in relation tothe interests of the Romanian state, particularly those relating to the economy, in the hope of reinvigorating the commercial relations between the two countries, while those from Odessa and Ismail were created immediately after 1878. Similarly, in the early 1880s, the Romanian consul from Odessa had the idea of establishing a Romanian consulate in Chișinău, but the Romanian minister of Foreign Affairs discarded Cristian Bălașa's idea. Only in May 1917, the Romanian policymakers decided to open consulates in Chișinău and $\mathrm{Kiev}^{4}$. Likewise, in 1913, on economic grounds, the decision was taken to open the honorary consulate in Riga ${ }^{5}$.

The establishment of a Romanian consulate in Ismail was a necessary move for the Romanian state, given that the return of the three counties from Southern Bessarabia back to the Russian Empire had left a large Romanian population in this region. Opened in 1878, the consulate in Ismail was discontinued after five

2 Organizarea instituțională a Ministerului Afacerilor Externe, ed. by Ion Mamina, Gheorghe Neacșu, George Potra, Editura Fundaţiei Europene Titulescu, București, 2004, p. 415.

3 Ministerul Afacerilor Străine. Personalul administrației centrale; delegațiunii în Comisia Europeană a Dunării; serviciului diplomatic; serviciului consular și tribunalului maritim Galați. 15 noiembrie 1911, Imprimeria Statului, București, 1911, p. 39-40.

4 Adrian-Bogdan Ceobanu, Politică și diplomație la sfârșitul secolului XIX. Din istoria relațiilor româno-ruse (1878-1899), Editura Universității „Alexandru Ioan Cuza” din Iași, 2017, p. 319.

5 AMAE, Fond Petrograd, vol. 43, Problema Consulate-Riga, nepaginat. 
years. Only several years later did the issue of restoring the consulate in Ismail reemerge. In August 1891, the secretary of the Russian legation in Bucharest brought to the notice of the Romanian minister of Foreign Affairs that the Russian authorities do not oppose the reopening of the consulate in Ismail; the Russian diplomats highlighted the difficulties at the Russian-Romanian border crossings. The Romanian minister admitted, in early 1892 , that at that moment there were not that many consulates opened in neighboring countries, and that those existing were far from the state borders. This was even more obvious in the case of the consular network in the Russian Empire, where there was only one remunerated consular position, namely in Ismail ${ }^{6}$. The presentation by the Minister of Foreign Affairs Alexandru Lahovary, on 10 April 1892, of a special report in front of the Council of Ministers, prompted the issuance of the decree to re-establish the consulate in Ismail. From this moment until March 1918, the consular office functioned without interruption. It was led by the consul, assisted by an interpreter and an usher; the number of functionaries could vary every year. The chief of the consular mission most often maintained a correspondence with the chief of the Legation in Petersburg, and in some cases, such as during the Great War, directly with the Minster of Foreign Affairs. For instance, in July 1917, the personnel of the consulate in Ismail consisted of only the consul and the interpreter, while that from Odessa was slightly more numerous, including the consul, the vice-consul and two interpreters ${ }^{7}$.

When World War I began, the Romanian consulate in Ismail was led by Sebastian Grecianu (b. September 1858, Botoșani). He held various positions throughout his career: chancellor in the consulate in Ismail from April 1894, then in Czernowitz from the following year. On 1 April 1912, he was appointed to Ismail, replacing Stamate Stamatiad, who was transferred to Odessa. Grecianu's activity was commendable, particularly during the events of May 1912, when, in the context of the festivities/commemorations taking place in Bessarabia, on the occasion of the $100^{\text {th }}$ anniversary of the annexation, he refused to display the flag on the consulate and to attend the Te Deum. His conduct annoyed the chief of the local gendarmerie, who forwarded the account to the authorities in Chișinău 8 .

Grecianu's reports, as those of his successor, are found in the Archive of the Romanian Ministry of Foreign Affairs and contain various kinds of information for the period 1914-1916. They range from extracts from the Russian press

${ }^{6}$ Adrian-Bogdan Ceobanu, op. cit., p. 322-323.

7 AMAE, Fond Petrograd, vol. 43, Problema Consulate-Odessa, nepaginat.

8 Dinu Poștarencu, Protestul consulului român de la Ismail vizavi de sărbătorirea centenarului anexării Basarabiei la Imperiul Rus,in:Românii din afara granițelor țării. Istorie, cultură, civilizație, coord. Iulian Pruteanu-Isăcescu, Casa Editorială Demiurg, Iași, 2011, p. 78-79. 
on the attitude of Romania in the new context, or on the relations of the Old Kingdom with Russia and Austria-Hungary, to the attitude of the local population towards the course of events. For example, his reports from the summer of 1914 emphasize that "manifestations in favor of the Serbs are constantly taking place in Bessarabia and in the rest of the Empire. The mobilization order was received with great enthusiasm across the entire province. In Ismail, on the $17^{\text {th }}$ and $18^{\text {th }}$ of the current month there were several patriotic demonstrations, two of which were held in front of the General Consulate". These events took the representative of the Romanian state by surprise. On the evening of 17 July, on the street where the consulate was located, the demonstrators sang the Russian anthem, and when Grecianu appeared they shouted "Long live Romania! Long live King Carol I". From within the crowd, the consul moved to the balcony of the residence, from where he thanked those present for the friendly displays toward Romania, returning the salute: "Long live H.M. the Tsar, long live Russia!". New "demonstrations of friendship" took place in front of the consulate the following day, but this time Grecianu did not appear before the crowd ${ }^{9}$. The behavior of the consul may seem surprising, but it can be partially explained. Against the backdrop of various rumors concerning Romania's position in the context of the events in South-Eastern Europe, any sign or gesture by an official representative could have been subjected to unwarranted interpretation, either by the Russian officials or by other members of the consular body.

\section{Romania in the Context of the First World War}

The alliance between Romania and Austria-Hungary, signed on 18/30 October 1883 , to which Germany was admitted on the same day, followed by Italy five years later, was the guiding document of Romania's foreign policy up until World War I. In 1914, two important events changed the subsequent evolution of Romania's foreign policy: the breakout of the Great War, and the death of King Carol $\mathrm{I}^{10}$. On the other hand, around this time, the Romanian-Russian relations had overcome the tensions prevailing at the end of the $19^{\text {th }}$ century. Various factors contributed to this situation: the countless dynastic visits (the heir apparent Prince Ferdinand and Mary went to Russia in May 1896, May 1908 and March 1914, King Carol alongside Prince Ferdinand in July 1898, and several members of the Russian imperial family visited Romania in 1896, 1902 and 1907, culmi-

9 AMAE, Fond Primul război mondial, vol. 14, dosar 71/1914 E2 Ismail, f. 280-281.

${ }^{10}$ Rudolf Dinu, „Aliatul inamic” România și chestiunea războiului contra Imperiilor Centrale (19141916), în Marele Război și Europa danubiano-balcanică, coord. Francesco Guida, Romanian version edited by Ana-Victoria Sima, Monica Fekete, Presa Universitară Clujeană, Cluj-Napoca, 2016, p. 58-75. 
nating with the visit of Tsar Nicholas II to Constanța in June 1914), the lack of any major incidents between the two states that would lead to a state of conflict, but also the presence in Bucharest and Petersburg of diplomats aware of the importance of the positions they held ${ }^{11}$. After the decision to stay neutral was taken by the Crown Council on 21 July/3 August 1914, the Liberal Prime Minister Ion I.C. Brătianu, alongside Romania's envoy to Petersburg, Constantin Diamandi, carried out negotiations with Russian diplomats. The talks initiated on $23 \mathrm{July} / 5$ August materialized into a special agreement signed on 18 September / 1 October $1914^{12}$.

From the autumn of 1914 until August 1916, the Romanian-Russian negotiations were increasingly frequent and systematic. Years later, Diamandi recalled in his memoirs the difficult situation in which Romania found itself at that moment: "In fact, we had two Alsaces, one was Transylvania, and the other was Bessarabia. One thing was for sure, Romania could not have remained neutral in a conflict in which the issue of nationality that was promoted by the Entente countries was being discussed and maybe solved (...) What our allies wanted first and foremost was Romania's agreement to join them and its entrance into the war. For them, this was the main issue; for us, however, the main issue was to ensure the future of our country"13. This last phrase perhaps best underscores Romania's position during the war. The national interest prevailed over any other considerations.

During the period of neutrality, an important role in taking decisions was played by the Liberal Prime Minister Ion I.C. Brătianu, who carried out negotiations, which were ultimately successful, with the representatives of the Entente

${ }^{11}$ Adrian-Bogdan Ceobanu, Câteva documente otomane privitoare la relaţiile româno-ruse (mai-iunie 1914), în „Anuarul Institutului de Istorie „A. D. Xenopol”, t. LI, 2014, p. 393-402.

${ }^{12}$ Russia pledged to oppose all threats against the territorial status quo of Romania within its current borders; the acknowledgement of Romania's right to annex the regions inhabited by Romanians from the Austro-Hungarian monarchy, with a special case for Bukovina, where the principle of population majority will serve as the basis for delimiting the territories annexed by Russia and Romania, respectively. This border delimitation was to be carried out following studies concerning these regions conducted by a mixed commission designated for this purpose, on the basis of the conciliatory spirit of the two governments; Romania will occupy the aforementioned territories at the opportune moment; Russia will ensure that these agreements will be approved by the governmentsin London and Paris, while Romania will guarantee a favorable neutrality towards Russia until the occupation of the abovementioned territories was complete (Iana Bălan, Rusia și neutralitatea României. Convenția din 1914 în România și statele vecine la inceputul primului război mondial. Viziuni, percepții, interpretări, eds. Flavius Solomon, Andrei Cușco, Mihai-Ștefan Ceaușu, Editura Universității „Alexandru Ioan Cuza,” Iași, 2016, p. 149).

${ }^{13}$ C. Diamandy, Cum s-a negociat harta României Mari, în România în timpul primului război mondial. Mărturii documentare, vol. I, 1914-1916, Bucureşti, 1996, p. 172-173. 
in order to attain the territorial goals the government aspired to: Transylvania, Bukovina up to the River Prut, and the Banat up to the Tisza ${ }^{14}$. Several days after the signing of the political convention with the Allies (4 / 17 August 1916), Romania declared war on Austria-Hungary. After almost four decades since the war of 1877, Romania and Russia were again joining forces. However, several defeats inflicted on the Romanian armies in the autumn of 1916 directly influenced the subsequent fate of the Romanian state: on 23 November / 6 December the German armies occupied the Romanian capital. The government and a part of the population took refuge in Iași, while the Romanian state treasure was sent to Moscow ${ }^{15}$.

\section{The Events of 1917 From G. Forescu's Perspective}

In December 1916, Sebastian Grecianu was transferred to Odessa. Instead, Gheorghe Forescu was designated as the new Romanian consul in Ismail. Born in 1871 in Fălticeni, Forescu entered the central administration of the Ministry of Foreign Affairs in December 1895. He held various posts within the Ministry: junior clerk, editor, office sub-director, chancellor and vice-consul in Salonica, chancellor of the Romanian Legation to Constantinople. Starting from 1914, he returned to the Ministry's central headquarters, within the Consular Division. In November he was named temporarily in charge of the Ismail consulate, arriving to reclaim his new position in December 1916. Upon his arrival to Ismail, he received the official "regrets for the recent German successes in Romania" from the local authorities. Forescu also encountered a number of practical problems, including the high cost of living and the lack of street lighting, so that he was compelled to travel to Galați in order to replenish his oil and candle supply ${ }^{16}$.

In late 1916, the military and general strategic position of Bessarabia was steadily worsening. The main danger came from the southern direction, since the Bulgarian troops, supported by the German army, had entered Northern Dobrogea and had reached the Lower Danube. The situation had reached a point where, in 1917, the Germans held Ismail under regular artillery fire, rather frequently bombing some of the city's neighborhoods. Against the background of the events unfolding during the last month of 1916, Forescu, who had recently arrived in Ismail, retired to Odessa, while several of his diplomatic reports were drafted in that city. The city of Ismail was completely evacuated by the Russian authorities. Only the High Command of the Gendarmerie, the police chief and

\footnotetext{
${ }^{14}$ Rudolf Dinu, op. cit., p. 69-75.

${ }^{15}$ Constantin I. Stan, Aliați și adversari. Relațiile româno-ruse 1916-1920, Editura Paideia, București, 2006, p. 15-47.

${ }^{16}$ AMAE, Fond Problema 77, Litera F, nr. 14, nepaginat.
} 
the city hall were still functioning in the city. However, the archive of these institutions was evacuated to Simferopol, while a part of the population had departed either for Chilia Veche or for Odessa. The reason for this was rather simple: an intensive artillery fight had been raging for some time between the cities of Ismail and Tulcea, which had been occupied by the Germans. The Romanian consul also identified the main issues that plagued the Russian army: most of the soldiers were travelling from Odessa to Bender by train, and from there they had to walk to Ismail, which took between 8 and 10 days. Others had to travel by train to the station of Traian-Vad, and from there had to walk till they reached the banks of the Danube ${ }^{17}$. By late February of 1917, Forescu was back in Ismail, having thus the opportunity to better observe and describe the accelerating course of events in Southern Bessarabia.

„Everything started with the issue of bread. The bakeries in Petrograd, especially those located in the working class districts, had been empty for several weeks, and long queues were starting to appear (...) the bitter frosts and the arctic snowstorms had completely blocked all railway transports. The factories were closing. Thousands of workers who had been fired or dismissed were swarming through the streets"18. This was the image of the Russian Empire's capital in February 1917, an image which would ultimately result in social breakdown, leading to deep political and social changes. Among other factors contributing to this upheaval, one might add the increasing difficulties on the railway network and "the sudden deployment of hundreds of thousands of troops to the Romanian border after the collapse of the Romanian army in the face of the German offensive" 19 .

The events unfolding in February-March 1917, which ultimately led to the tsar's abdication, the fall of the Romanov dynasty and the establishment of a provisional government, could be increasingly felt throughout the empire's entire territory, including on the state's periphery. This was also true for Bessarabia, in general, and for the southern area of this province, in particular. On Sunday, 12 March 1917, the ceremony of the official oath of allegiance of the Russian troops present in town took place at Ismail's main church. At the end of the solemn religious service, on the Cathedral Square, the representative of the Provisional Government read the approved oath formula, and every group of soldiers took the oath according to their religious denomination. Incidents were thus bound to oc-

\footnotetext{
${ }^{17}$ AMAE, Fond Primul război mondial, vol. 14, dosar 89/1914 E2 Ismail, f. 64.

${ }_{18}$ Orlando Figes, Revoluția Rusă 1891-1924. Tragedia unui popor, translated by Cornelia Marinescu, Polirom, Iași, 2016, p. 297.

${ }^{19}$ Dominic Lieven, The End of Tsarist Russia. The March to World War I and Revolution, New York, 2015, p. 351-352.
} 
cur, especially clashes between corporals, NCOs and soldiers. Speeches held by various officers were also part of the picture ${ }^{20}$. The Romanian consul was keen on acquiring more information about the general mood and tendencies within the ranks of the Russian army. Following a conversation with Admiral Fabriski, the consul became aware of the latter's increasing worries in connection with the recent events in the empire: „the Russian people is still quite far from being adequately prepared for such a great degree of freedom, and the current moment was not at all appropriate for such a radical change."21 A month later, things seemed to slowly go back to normal. The discipline had been seemingly restored within the soldiers' ranks. An important role in this task belonged to the officers, who urged the soldiers under their command to put more emphasis on discipline. Otherwise, „if the Germans emerge victorious, then the Russian people will lose all the freedoms it had acquired, since the victors will support the former regime, with which they purportedly had connections, and they will restore the tsar to the throne, under their shield and leadership." 22 These appearances were but illusory. In mid-April, new cases of lack of discipline emerged. Moreover, the number of desertions had grown alarmingly, reaching almost 1000 cases. The representatives of the Provisional Government had to be sent to Bolgrad in order to calm down the situation a bit. ${ }^{23}$

Another aspect that the Romanian consul in Ismail had to deal with involved cases of espionage, which were quite frequent in that area. Only during the months of March and April 1917, around 45 spies could be identified, most of them children and teenagers, aged between 14 and 18. The strategy for their recruitment was not complicated at all: the youngsters were lured by various agents of the Germans, paid a daily amount of five lei and then sent to a special school of espionage which had been created in Bucharest. After attending a number of courses, the recruits were examined at the Headquarters of the German Navy. Subsequently, some of them were sent by train to Brăila, and from there they were further dispatched to Tulcea, being constantly accompanied by a German officer in civilian dress. In Tulcea, they were transferred to the custody of other German officers, who sent them further to various neighboring areas with the help of the Old Believers. ${ }^{24}$ Several months later, Forescu wrote an analytical report on the activity of the Directorate of the Romanian Secret Police (Siguranța) in Southern Bessarabia and the area of the Danube Delta. This was prompted by the fact, that

\footnotetext{
${ }^{20}$ AMAE, Fond Primul război mondial, vol. 14, dosar 89/1914 E2 Ismail, f. 6.

${ }^{21}$ Ibidem, f. 7.

${ }^{22}$ Ibidem, f. 16.

${ }^{23}$ Ibidem, f. 25.

${ }^{24}$ Ibidem, f. 17.
} 
large-scale espionage and anti-war propaganda were rife in that region. Forescu noted that the trained security personnel wasinsufficient and poorly paid. $\mathrm{He}$ also drew the attention of his superiors to the phenomenon of Romanian deserters and to their subversive actions. Forescu was also unhappy because of the activity of the Russian consul in Sulina, who supported an open anti-Romanian propaganda campaign within the ranks of Russian soldiers. The Romanian official recommended to his superiors to demand, on the nearest occasion, the replacement of this diplomat, which would apparently bring „a greater degree of calm to the entire Delta." He also suggested that the number of the Siguranţa-affiliated personnel be supplemented, as well as an increase of their wages. His conclusion was rather clear: the service of the Siguranța deserved much more attention. ${ }^{25}$

Against the background of the radical social and political changes occurring in the Russian Empire, one could also witness the growing assertiveness of the national movement in Bessarabia. In this sense, the Committee of Bessarabian soldiers and officers in Odessa played a crucial role. ${ }^{26}$ During its meeting held on 30 March 1917, it adopted a resolution creating the Moldavian Progressive Party of the Bessarabian Officers and Soldiers from the Odessa Garrison. The new party's program stipulated, among other things, Bessarabia's autonomy and the introduction of the Romanian language in the local schools, church, and administration. On 19 April 1917, the political program of the Moldavian National Party was adopted. ${ }^{27}$ During the same period, the Romanian consul in Ismail drew the attention of the political leaders in Iași to a particularly interesting aspect of the situation: following the manifestations in Odessa which demanded Bessarabia's autonomy, among some "local elements" in Ismail more and more frequent discussions concerning a possible "integration of this province into the Kingdom" (alipirea acestei Provincii la Regat) could be registered..$^{28}$ At the same time, taking into account the presence in Ismail of a growing number of Romanian refugees, Forescu supported the initiative to establish a mixed primary school. He wrote to the government in Iași, requesting that the necessary books for the instruction of approximately 130 children be sent from the temporary Romanian capital. The future teachers were to be recruited among the young women who had a professional diploma or certificate or who had graduated from the higher grades in the

${ }^{25}$ Ibidem, f. $72-74$.

${ }^{26}$ On 26 March 1917, in a report sent to the Liberal Prime Minister, Ion I. C. Brătianu, the Romanian consul in Odessa analyzed the events taking place in southern Russia, emphasizing that, a happy and gratifying fact for us, stemming from the new democratic and liberal situation, is the reawakening of the national feelings among the Romanians living in Bessarabia and here [in Odessa]”. (AMAE, Fond Primul război mondial, Fond 71/1914 E2, dosar 172, f. 7).

${ }^{27}$ Vitalie N. Ciobanu, Militarii basarabeni 1917-1918. Studiu și documente, Chișinău, 2010, p. 42-43.

28 AMAE, Fond Primul război mondial, vol. 14, dosar 89/1914 E2 Ismail, f. 25. 
schools of the Old Kingdom..$^{29}$ After several telegrams had been exchanged between the Ministry of Foreign Affairs and the Ministry of Public Instruction, two months later, in June 1917, a final decision was reached to create such a school in Ismail. During the same period, the Romanian element of the town's population discussed "openly and without any restraint" about Bessarabia's unification with Romania, since "this province could not remain, in the future, within the Slavic spheres of Russia." ${ }^{30}$ Simultaneously, the committee of the Moldavian National Party openly advocated the introduction of Romanian in the school system of the Bessarabian province, but also the opening of special religious seminaries for Moldavian students. ${ }^{31}$

Closely following the situation that prevailed, at that time, in the towns of Southern Bessarabia, Forescu drafted a special memorandum on the topic of „The Cultural-Nationalist Question”. As a result of his analysis, he concluded that „the Romanian peasants preferred not to send their children to the Russian schools at all, in order for the latter not to forget their native language and not to become de-nationalized." This was in contrast to most members of the Bessarabian nobility. The nationalist manifestations occurring during the recent months also led him to the conclusion that, within this province, "deep down, the profound feeling of Romanian nationality still existed, and that it is still the strongest." The most intensive and systematic political activity was visible in Chișinău, where "all the true and good Romanians gathered around [the journal -B. C.] Cuvânt moldovenesc. It is from here that all the publications were distributed, reaching as far as the lands beyond the Dniester; spanning the length of this river alone, there were approximately 500.000 Romanians living there". The Romanian consul also insisted on the creation of as many schools as possible, in Southern Bessarabia, devoted to the instruction of the children of the Romanian refugees. Thus, the chances increased for other children from Bessarabia to eventually join these schools. Forescu also tirelessly campaigned for as many books, journals and church literature publications as possible to be sent to the region. ${ }^{32}$ In the fall of 1917, the Romanian consul particularly noticed the activity initiated and pursued by the teacher Lungu, from Chișinău, but also by D. Bădărău, "the only person who has the courage to speak everywhere, as a true and good Romanian that he is, about the union of Bessarabia and Romania." Bădărău had already been "included, under the former regime, in the black book [of Tsarism - B.C.] for

\footnotetext{
${ }^{29}$ Ibidem, f. 32.

${ }^{30}$ Ibidem, f. 47.

${ }^{31}$ Vitalie N. Ciobanu, op. cit., p. 44.

32 AMAE, Fond Primul război mondial, vol. 14, dosar 89/1914 E2 Ismail, f. 51-52.
} 
his philo-Romanianism." ${ }^{33}$ Already in mid-October 1917, at the main Cathedral, during the Orthodox liturgy, the church choir sang in Romanian. Also, in the St. Nicholas Church, the divine service was alternatively officiated in Romanian and Russian. ${ }^{34}$

Meanwhile, a special delegation of Bessarabian leaders participated at the Congress of the Peoples of Russia, held in Kiev. This Congress confirmed and upheld the right of all peoples to national and personal self-determination. As a representative of the interests of the Bessarabian Romanians, Teofil Ioncu rejected any possibility for Bessarabia to be simply transformed and reduced into an ordinary region or province of the Ukraine. ${ }^{35}$ A month later, in October 1917, the Congress of Moldavian Soldiers and Officers was convened in Chișinău. Around 800 delegates were present at the Congress, representing the interests of approximately 25000 soldiers. Although several crucial decisions were taken during the meeting, two of these proved decisive for the future of the land situated between the Prut and the Dniester: the proclamation of territorial autonomy and the creation of Sfatul Țării, a provincial assembly consisting of 120 members, with another 10 seats reserved for the Romanians from beyond the Dniester. This assembly became Bessarabia's official governing body. ${ }^{36}$ On the other hand, on 25 October / 7 November 1917, the Bolshevik military formations overthrew the Provisional Government in Petrograd, which had been under the leadership of Alexandr Kerenskii. The foreign military intervention, in particular the German advance, had an important role in the ultimate success of the Bolsheviks. ${ }^{37}$ Here is an excerpt from the memories of the Romanian diplomat Nicolae B. Cantacuzino, who was at the time the secretary of the Romanian Legation in Petrograd, in connection with those decisive events: „On the night of November 6-7, very early in the morning, I was awoken by the deafening noise of roaring canons. Without any hesitation, I put on the simplest possible outfit, with a worker's cap covering my head, and I proceeded toward the Winter Palace, from where the loud noise of the canons was coming, which, however, did not last too long there. (...) The Bolshevik Revolution had triumphed, without any doubt and almost without any struggle."38

${ }^{33}$ Ibidem, f. 84-85.

${ }^{34}$ Ibidem, f. 87.

${ }^{35}$ Petre Cazacu, Moldova dintre Prut și Nistru 1812-1918, Chișinău, 1992, p.282-287.

${ }^{36}$ Valeriu Popovschi, Biroul de organizare al Sfatului Țării (27 octombrie-21 noiembrie 1917)/Republica Democratică Moldovenească (Formarea și evoluția. 1917-1918), edited by Gheorghe E. Cojocaru, Editura Academiei Române, București, 2017, p. 25-27.

${ }^{37}$ Dominic Lieven, op. cit., p. 355-357.

${ }^{38}$ Nicolae B. Cantacuzino, Amintirile unui diplomat român, foreword by N. Iorga, edited by Adrian Anghelescu, Ed. Apollonia, Iași, 1994, p.129-130. 
In December 1917, the Romanian consul in Ismail astutely reported on the chaos and disorder reigning in the villages and towns of Southern Bessarabia: "On the day of 1 December of the current year, a gang of thieves, dressed in soldiers' uniforms, numbering over 200 people, have wreaked havoc, pillaged and set on fire a number of shops and several private houses from the city of Cahul. During the whole havoc, some soldiers belonging to the regular army also joined this gang. On the day of 3 December, the robbing, pillaging and the deliberate fires spread first to all the nobles' manors situated on rural landholdings, and then to the city of Bolgrad, where these gangs pillaged and destroyed several warehouses and private dwellings, subsequently setting two of these on fire." ${ }^{39}$ In Ismail itself, however, no such events took place. The local Soldiers' Committee had a very important role in keeping the peace and preserving public order throughout the city. ${ }^{40}$ Still, this calm situation was only apparent, because fear had gripped most of the inhabitants. The newspapers did not reach the city anymore, not even those printed in Odessa, and the news coming from private sources or through hearsay could not be verified in any way. ${ }^{41}$

The breaking of diplomatic relations between Romania and Soviet Russia in January 1918 and the ensuing departure of the Romanian diplomatic mission from Petrograd did not, however, also lead to the closing of the Romanian consulate in Ismail. All this notwithstanding, Forescu had been warned by the chief of the Danube Delta section of the Romanian Siguranța that it would be better to transport all the confidential papers to Romania proper, in order to avoid their confiscation. Under these circumstances, the consul passed the Danube to Romania, carrying with him all the ciphers, the confidential diplomatic correspondence and the seals, which he then left in the care of a certain Commander Șendrea ${ }^{42}$. At the same time, in Ismail, the consulate's official interpreter received the unexpected visit of 10 individuals dressed in a Russian military uniform, who were rather curious concerning the hiding place purportedly used by the consul to conceal weapons. The interpreter answered that Forescu was out of town, having left for Chilia, and that the only weapon he owned was a small revolver without any cartridges. These men finally left after failing to find anything; however, the next day another group consisting of five men, also dressed in a Russian military uniform, but speaking Romanian this time, paid another visit to the consulate, insisting that the interpreter hand over to them "the consul, the safe with the consulate's money and all the Romanian officers." They

\footnotetext{
${ }^{39}$ AMAE, Fond Petrograd, vol. 42, Dosar referitor la consulate/Ismail, nepaginat.

${ }^{40}$ Ibidem.

${ }^{41}$ Ibidem, telegram sent on 15 December 1917.

${ }^{42}$ AMAE, Fond Primul război mondial, vol. 14, dosar 89/1914 E2 Ismail, f. 58.
} 
received the same answer, but before leaving managed to destroy the portraits of the king and queen of Romania. ${ }^{43}$ Against the background of the continuing simmering tensions in Southern Bessarabia, Forescu suggested that the publication of a Russian-Romanian newspaper was necessary in order to initially pursue the line of "propaganda for calm" in the region. He also suggested the sending of a number of newspapers from Romania to Southern Bessarabia, which would be distributed for free to the local population, but also the dispatching to the region of several Romanian priests. ${ }^{44}$ At the end of March 1918, the consulate in Ismail was abolished as a consequence of Bessarabia's union with Romania. The former consul, Gh. Forescu, was recalled to the central administration of the Foreign Ministry. He continued his diplomatic activity during the following decades. The authorities in Iași demanded that the consulate's archive be brought with him there. The consulate's furniture and other remaining property were to be sold at a special auction. ${ }^{45}$

\section{Conclusion}

At the end of 1916, Gheorghe Forescu became the new Romanian consul in Ismail, a city situated in Southern Bessarabia, which at that time was a province of the Russian Empire. In the context of World War I and Romania's joining the Entente in August 1916, Russia and Romania had signed a formal alliance treaty. Nothing could have predicted the turmoil and upheaval which would engulf the empire during 1917. However, the Romanian consul quickly adapted to the changing situation. More often than not, Forescu had to confront and overcome certain difficult moments, having to take rapid and tough decisions. Most significantly, he formulated policy initiatives that were generally taken into account by the Romanian decision-makers. He held a position which could initially seem not very demanding and rather ordinary, but which proved to be a crucial point of observation in the context of the accelerating pace of events within the Russian Empire more generally and in Bessarabia, in particular. In late March 1918, Forescu completed his diplomatic mission in Ismail for a rather peculiar and extraordinary reason in the history of Romanian diplomacy: the city that he had been appointed to by the Romanian authorities had become a part of the Romanian Kingdom.

${ }^{43}$ Ibidem, f. 100-101.

${ }^{44}$ Ibidem, f. 166.

${ }^{45}$ AMAE, Fond Problema 77, Litera F, nr. 14, nepaginat. 


\section{Rezumat}

Ecourile evenimentelor petrecute pe teritoriul Rusiei, în primăvara anului 1917, s-au resimțit și în Basarabia, provincie anexată în 1812. Evoluția acestora poate fi analizată din mai multe puncte de vedere, inclusiv din perspectiva unui reprezentant oficial al statului român. În aceste condiții, ne propunem ca, pe baza rapoartelor trimise de consulul României la Ismail, să observăm situația politică, socială și militară din Sudul Basarabiei într-o perioadă cu implicații profunde asupra Imperiului Rus, în general, şi asupra acestei provincii, în particular. Gheorghe Forescu a fost numit la Ismail, mai întâi în calitate de gerant al postului, în noiembrie 1916, iar mai apoi consul, o lună mai târziu. A rămas în sudul Basarabiei până în martie 1918, când postul consular a fost desființat, ca urmare a Unirii Basarabiei cu România. De cele mai multe ori, Forescu s-a aflat în fața unor momente dificile, a fost nevoit să ia decizii grele și, poate cel mai important, a avut inițiative, de care factorii decizionali români au ținut cont. Se afla într-un post, ce putea părea, la început, facil, dar care s-a dovedit a fi unul destul de important, de observaţie pentru evenimentele din Imperiul Rus, în general, şi pentru Basarabia, în mod particular.

Cuvinte-cheie: Basarabia, Ismail, consul, Imperiul Rus. 